\title{
Effects of the Addition of Pure Glycerin Supplementation in the Drinking Water on the Performance of Broilers Submitted to Heat Stress and Feed Restriction
}

-Author(s)

\author{
Moraes PO \\ Ceron MS' \\ Borille R' \\ Gianluppi RDF' \\ Lovato $\mathrm{GD}^{\prime}$ \\ Cardinal KM \\ Ribeiro $A M L^{\prime}$
}

Federal University of Rio Grande do Sul, Department of Animal Science, Porto Alegre, RS, Brazil.

\begin{abstract}
The experiment was conducted to study the effect of pure glycerin supplementation (GLYC) in the drinking water of broilers subjected to heat stress and feed restriction. Water with 0,1 , or $2 \%$ glycerin was provided ad libitum to broilers in six hours of feed restriction. The birds were housed in two environments: thermoneutral (TN) $-25^{\circ} \mathrm{C}$, and cyclic heat stress (HS) - $12 \mathrm{~h}$ with $25^{\circ} \mathrm{C}$, $6 \mathrm{~h}$ with $32^{\circ} \mathrm{C}$, 3h of $25^{\circ}$ to $32^{\circ} \mathrm{C}$ and $3 \mathrm{~h}$ of $32^{\circ}$ to $25^{\circ} \mathrm{C}$. The experimental design was randomized in a factorial arrangement of $2 \times 3+2$, with three GLYC levels, two environments and one control group with ad libitum feeding each environment. When submitted to HS, broiler receiving $2 \%$ glycerin presented higher weight gain (WG), water consumption (WC), feed intake (FI) and energy consumption (EI) than those in the other treatments, contrarily to birds in TN, where increasing GLYC levels decreased those responses. Broilers submitted to feed restriction presented reduced $\mathrm{Fl}$, but better feed conversion (FCR), independently of rearing environment or GLYC levels. Broilers under HS submitted to feed restriction and receiving 2\% GLYC presented higher WC $(p<0.05)$ and similar WG as the controls, differently from the restricted-fed broilers under TN receiving $2 \%$ GLYC, which WC and WG were lower than the controls. The inclusion of $2 \%$ pure glycerin in the drinking water may compensate the negative effects on performance caused by feed restriction in broilers submitted to heat stress.
\end{abstract}

\section{INTRODUCTION}

Studies on glycerol consumption via drinking water for animals and human athletes have shown that this substance has hyper-moisturizing properties due to the osmotic effect of glycerol in the body, supporting body fluid regulation when physical activities are performed in high environmental temperatures (Schott et al., 2001; Coutts et al., 2002; Kavouras et al., 2006; Patlar et al., 2012).

The survival of poultry under heat stress largely depends on water consumption, because this nutrient is associated with thermoregulatory mechanisms. The capacity of an animal to regulate its body temperature depends on the balance between heat production and heat dissipation (Yalçin et al., 1997). In high temperature environments, chickens decrease their feed intake to reduce the heat increment produced from feed metabolism, resulting in worse performance (Macari et al., 2002; Ribeiro et al., 2008; Oba et al., 2012).

An alternative method to help to control body temperature restriction feed offer before and during the hottest hours of the day. Reducing feed intake decreased the metabolic rate, and therefore, body temperature. Several studies showed that the body temperature and the mortality rate of broilers under heat stress submitted to feed restriction are reduced (Yahavet al., 1996; De Basilio et al., 2001; Yalçin et al., 1997). However, the reduced feed intake resulting from feed restriction leads 
Moraes POM, Ceron MS, Borille R, Gianluppi RDF, Lovato GD, Cardinal KM, Ribeiro AML
Effects of the Addition of Pure Glycerin

Supplementation in the Drinking Water on the Performance of Broilers Submitted to Heat Stress and Feed Restriction

All birds were fed a diet based on corn and soybean meal (Table 1), formulated to meet the broilers'nutritional requirements (Rostagno et al., 2011). In each room, a control treatment, in which birds were fed ad libitum, was maintained

Table1 - Ingredients and calculated nutritional composition of the diets fed to broilers between 35-42 days of age.

water consumption. Although there are many studies showed positive results of the glycerin as an energy supplement for athlete animals and humans on hot days (Schott et al., 2001; Kavouras et al., 2006; Dozier et al., 2008; Patlar et al., 2012; Romano et al., 2014), there are no studies on the effects of glycerin inclusion in the drinking water of broilers submitted to heat stress. Therefore, the objective of this study was to evaluate the supplementation of pure glycerin the drinking water on the performance of broilers submitted to feed restriction and to cyclic heat stress.

\section{MATERIAL AND METHODS}

Pure GLYC (99\% glycerol) levels of 0 , 1 , or $2 \%$ were supplied to broilers kept under heat stress and total feed restriction during hottest part of the day (for six hours) for a period of seven days. Glycerin was daily mixed with the drinking water in 20-L containers, and kept cool until the mixture was placed in the drinkers.

Two hundred and forty 35-d-old male Cobb broilers, with2158 $\pm 69 \mathrm{~g}$ body initial weight, were housed in cages, equipped with tube feeders and trough drinkers, divided into two rooms: TN (thermoneutral environment) and HS (cyclic heat stress). Cyclic HS consisted of 12 hours at $25^{\circ} \mathrm{C}$, three hours of temperature increase from 25 to $32{ }^{\circ} \mathrm{C}$, six hours at 32 ${ }^{\circ} \mathrm{C}$, and three hours of temperature decrease from 32 to $25^{\circ} \mathrm{C}$ daily, as shown in Figure 1 . In the TN room, daily temperatures ranged between 21 and $25^{\circ} \mathrm{C}$. Relative humidity was maintained at approximately $70 \%$ in both environments (Figure 1).
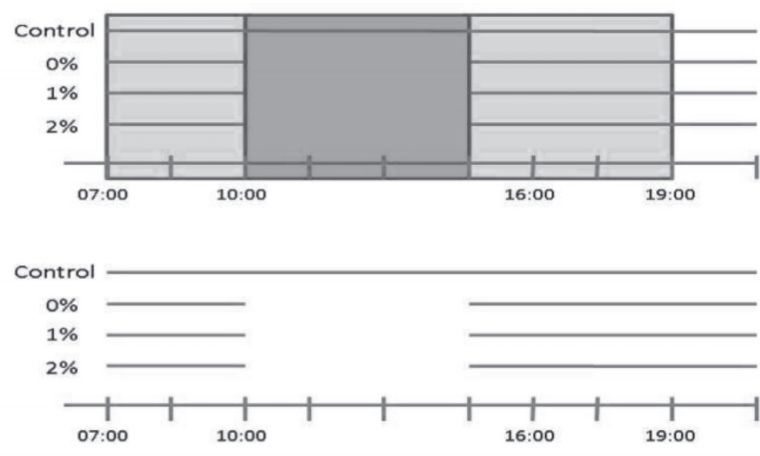

$\square 32^{\circ} \mathrm{C}$

$25-32^{\circ} \mathrm{C}$

$\square 25^{\circ} \mathrm{C}$

Figure 1 - Description of the daily temperature distribution in the thermoneutral (TN) and heat stress (HS) environments, and of the feed restriction period.

\begin{tabular}{|c|c|}
\hline Ingredient & Composition (\%) \\
\hline Corn & 63.48 \\
\hline Soybean meal (45\%) & 29.15 \\
\hline Soy oil & 4.25 \\
\hline Dicalcium phosphate & 1.11 \\
\hline Limestone & 0.84 \\
\hline Salt & 0.43 \\
\hline L-Lysine $\mathrm{HCl}$ & 0.24 \\
\hline DL-Methionine & 0.26 \\
\hline L-Threonine & 0.05 \\
\hline Mineral / vitamin premix ${ }^{1}$ & 0.12 \\
\hline Anticoccidial agent ${ }^{2}$ & 0.02 \\
\hline Choline chloride $60 \%$ & 0.04 \\
\hline \multicolumn{2}{|l|}{ Nutritional Composition } \\
\hline AMEn (kcal kg-1) & 3200.00 \\
\hline $\mathrm{CP}(\%)$ & 18.59 \\
\hline Calcium (\%) & 0.66 \\
\hline Available phosphorus & 0.31 \\
\hline Potassium (\%) & 0.72 \\
\hline Sodium (\%) & 0.19 \\
\hline Chlorine (\%) & 0.31 \\
\hline Lysine (\%) & 1.06 \\
\hline Methionine + Cystine (\%) & 0.77 \\
\hline
\end{tabular}

'Composition (content per kgpremix): 150,000 mg Mn, 100,000 mg Zn, 80,000 mg Fe, 15,000 mg Cu, 1,200 mg I, $700 \mathrm{mg} \mathrm{Se}, 23,200,000$ IU vitamin A, 5,600,000 IU vitamin $\mathrm{D}, 52,000 \mathrm{mg}$ vitamin $\mathrm{K}, 6,000$ mgvitamin B1, 18,000 mg vitamin B2, 9,000 mg vitamin B6, 13,2000 mgniacin, 44,000 mg pantothenic acid, 2,400 mgfolic acid, 200,000 $\mu$ gbiotin, 40,000 $\mu \mathrm{g}$ vitamin B12.

2Monensin - 100 ppm.

AMEn: apparent metabolizable energy corrected for nitrogen; CP: crude protein

Feed intake (FI) and water consumption (WC) were daily measured in two periods: during feed restriction (6 h) and during the subsequent period (18h). Weight gain (WG), feed conversion ratio (FCR), and mortality were determined at the end of the experimental period. Total energy intake (EI) was calculated as the sum of the feed and water energy intake. Daily feed energy intake was calculated as dietary metabolizable energy level multiplied by feed intake. Water energy intake was estimated as pure glycerin metabolizable energy level (3400 kcal/kg, according to Gianfelici, 2009) multiplied by water consumption.

Birds were distributed according to a completely randomized experimental design in a $2 \times 3+2$ arrangement, consisting of two environments (TN and HS) and three glycerol supplementation levels $(0 \%$, $1 \%$ and $2 \%$ ), plus one control group (receiving feed $a d$ 
Moraes POM, Ceron MS, Borille R,

Gianluppi RDF, Lovato GD,

Cardinal KM, Ribeiro AML
Effects of the Addition of Pure Glycerin

Supplementation in the Drinking Water on the Performance of Broilers Submitted to Heat Stress and Feed Restriction libitum) in each environment, totaling eight treatments with six replicates of five birds each.

Data were analyzed using PROC GLM (SAS 9.2). The factorial arrangement was analyzed by analysis of variance, and included the effects of glycerin supplementation levels, environment, and their interactions for all variables studied. The control (feed ad libitum) and feed restriction treatments were compared by three orthogonal contrasts for each environment: control vs. feed restriction with $0 \%$ glycerin, control vs. feed restriction with $1 \%$ glycerin, control vs. feed restriction with $2 \%$ glycerin.

\section{RESULTS AND DISCUSSION}

The analysis of the $2 \times 3$ factorial arrangement showed an interaction of GLYC levels with the environment for the parameters FI, WC, WG, and El during the restriction and subsequent period. Therefore, the main effects are not discussed, but the effects of GLYC supplementation levels in each environment.

In the HS environment, FI and WC were not different when birds consumed Oand 1\% GLYC; however, birds supplemented with $2 \%$ GLYC consumed more feed and water during both periods $(p<0.05)$ than the first two groups. On the other hand, in the TN environment, 0\% GLYC supplementation promoted the highest $\mathrm{FI}$ and the best FCR, and these parameters linearly worsened as supplementation levels increased (Figure 2, 3, 4 and 5). Under HS, the birds receiving $\%$ GLYC presented higher WG $(p<0.05)$ compared with those fed Oand $1 \%$ GLYC, which WG was similar ( $p>0.05)$, opposite to the WG results obtained in the TN environment, where $2 \%$ GLYC promoted the worst WG results (Figure 6). The worse performance observed with increasing GLYC levels in the broilers maintained in the TN environment was unique and not consistent with literature findings on the inclusion of GLYC as an energy source in the diet. Crude GLYC $( \pm 86 \%$ glycerol) can be included up to $50 \mathrm{~g} / \mathrm{kg}$ diet with no adverse effects on broiler performance (Cerrate et al., 2006; Guerra et al., 2011). The inclusion of high glycerol levels exceeds the metabolization capacity of the enzyme glycerol kinase, resulting in excessive glycerol excretion (Cerrate et al., 2006; Guerra et al., 2011). During the finisher phase, that inclusion level corresponded to $8.6 \mathrm{~g}$ glycerol daily intake, which is close to the $9 \mathrm{~g}$ consumed by the birds fed 2\% GLYC and kept under TN, therefore not characterized as excessive.

Under heat stress, high water consumption is beneficial, because water allows for evaporative heat loss in broilers (Smith \& Teeter, 1992). The latter observed that the water intake and weight gain of

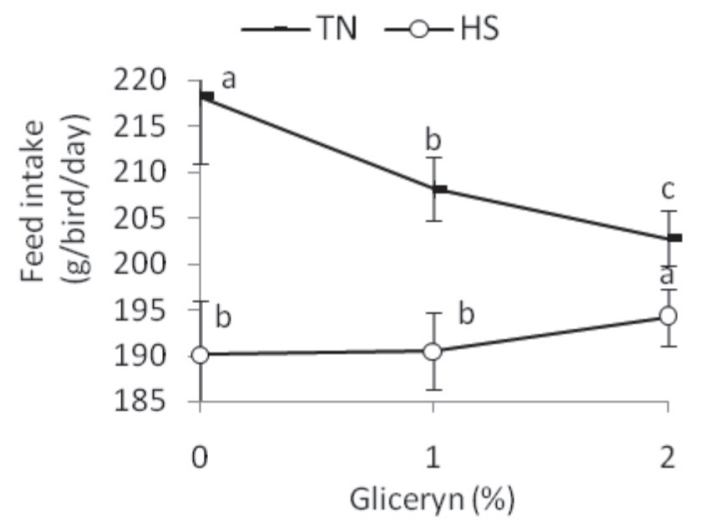

Figure 2 - Feed intake in TN and HS. Means \pm SE followed by different letters in the same row differ.

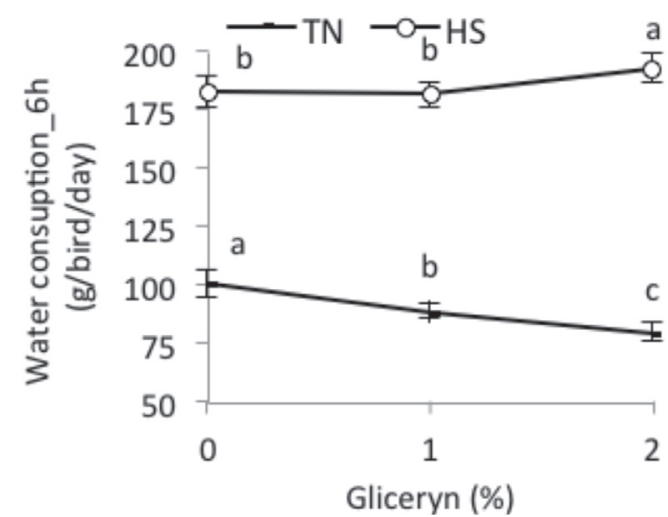

Figure 3 - Water consumption during the fasting period in TN and HS. Means \pm SE followed by different letters in the same row differ.

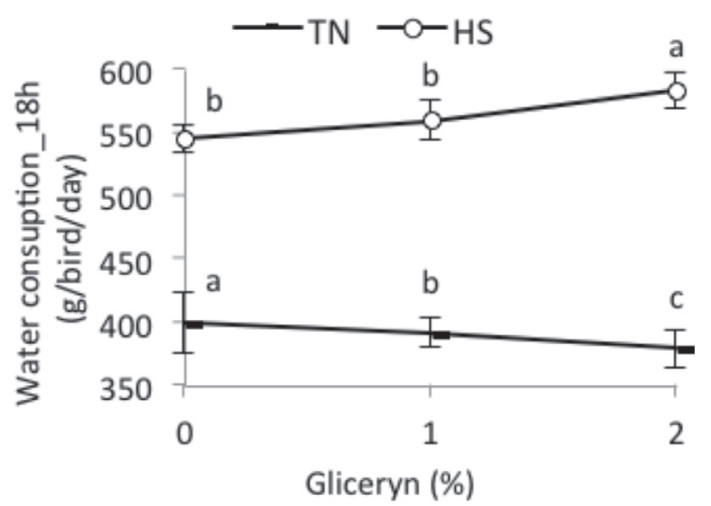

Figure $\mathbf{4}$ - Water consumption in $18 \mathrm{~h}$ of broilers in TN and HS. Means \pm SE followed by different letters in the same row differ.

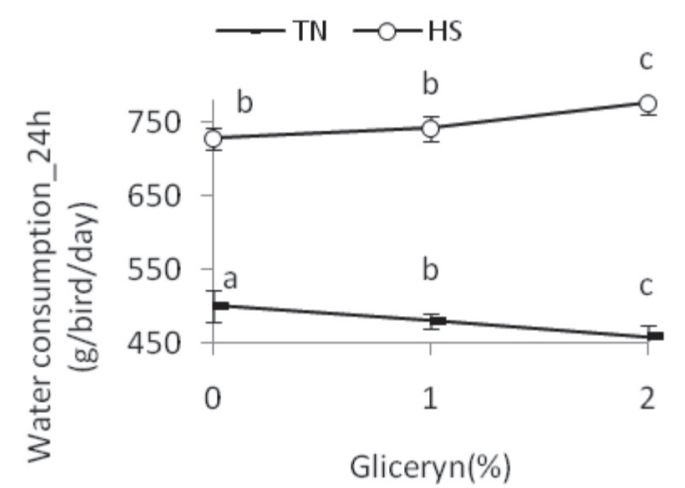

Figure $\mathbf{5}$ - Water consumption during $24 \mathrm{~h}$ in broilers at ATN and HS. Means \pm SE followed by different letters in the same row differ. 
Moraes POM, Ceron MS, Borille R,

Gianluppi RDF, Lovato GD,

Cardinal KM, Ribeiro AML
Effects of the Addition of Pure Glycerin

Supplementation in the Drinking Water on the Performance of Broilers Submitted to Heat Stress and Feed Restriction

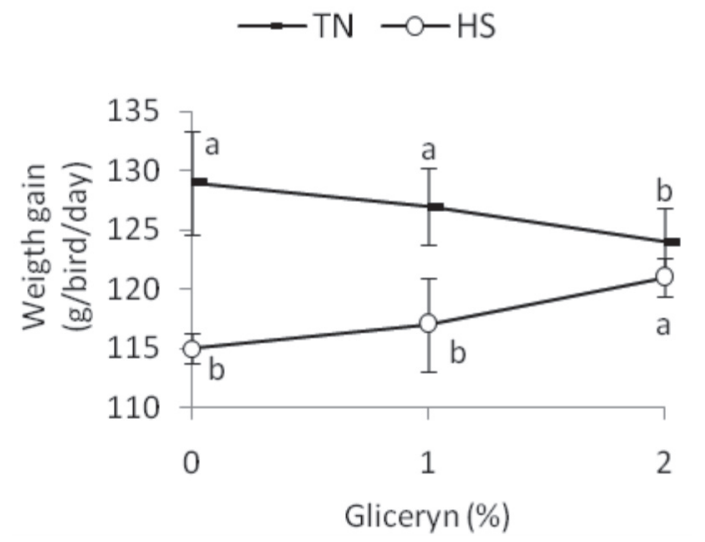

Figure $\mathbf{6}$ - Weight gain in TN and HS. Means \pm SE followed by different letters in the same row differ.

broilers under cyclic heat stress and supplemented with $0.2 \%$ potassium chloride via drinking water significantly increased, suggesting that higher weight gains are related with higher water consumption. According to Mushtaq et al. (2013), electrolyte intake, as it changes plasma osmolarity, induces thirst, causing the animal to drink more water. Similar to electrolytes, glycerol also changes plasma osmolality. Coutts et al. (2002) conducted a study with triathlete men consuming beverages with $1.2 \mathrm{~g}$ glycerol $/ \mathrm{kg}$ body weight and observed, when tests were performed on hot days, performance improvement, a reduction in urine output, and increased retention of body fluids compared with individuals in the placebo group. Likewise, Schott et al. (2001) administered glycerol in saline solution by nasogastricroute to horses and observed an increase in water intake and hence, a hyper-moisturizing effect. This induction of hyperhydration in high-temperature environments results in greater fluid retention compared with ingestion of pure water, and it is related to the rapid absorption and osmotic activity of glycerol (O'Brien et al., 2005).

In addition to its osmotic and moisturizing effect, increasing circulating levels of glycerol stimulate hepatic gluconeogenesis, increasing the number of substrates available for energy supply (Kavouras et al., 2006). Under HS, El was increased with increasing GLYC levels $(p<0.05)$, because the supplementation with $2 \%$ GLYC contributed with $53 \mathrm{kcal}$, in addition of the energy consumed in the feed. This may also have contributed to the higher WG observed in broilers receiving $2 \%$ GLYC and submitted to HS (Figure 6). Moreover, in the TN environment, 1 and 2\% GLYC in the drinking water reduced $\mathrm{El}$, suggesting that the addition of GLYC in the drinking water supplied part of the broilers' energy requirements, and therefore, they needed to obtain less energy from the diet (Figure 7), whereas in broilers maintained in HS presented lower feed intake.

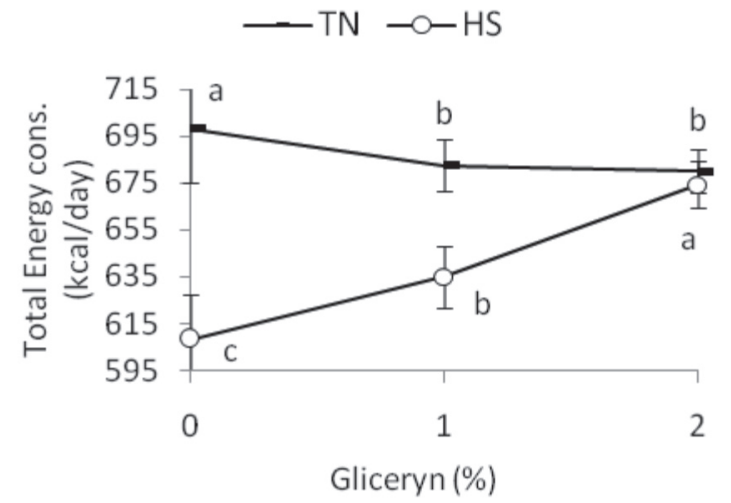

Figure 7 - Total broiler energy intake (feed +water) in TN and HS. Means \pm SE followed by different letters in the same row differ.

Under HS, the control group presented the worst FCR $(p<0.05)$, whereas the birds receiving $2 \%$ GLYC presented similar WG $(p>0.05)$ and higher WC $(p<0.05)$ than the controls, indicating that this level of GLYC supplementation in the drinking water may alleviate the adverse effects caused by feed restriction on broiler performance (Table 2 ). Broilers receiving $0 \%$ and $1 \%$ GLYC presented lower WG compared with the controls, but similar WC. In the TN environment, independently of GLYC level, the birds who suffered feed restriction consumed less feed and less water than the controls, but presented better FCR (Table 2),

Table 2 - Performance of broilers fed ad libitum (control) or submitted to feed restriction and supplemented with 0,1 , or $2 \%$ glycerin and reared in thermoneutral or heat-stress environments.

\begin{tabular}{lcccc}
\hline Heat stress & & & & \\
\hline & Fl_24h & WC_24h & WG & FCR \\
\hline Control & 219 & 730 & 118 & 1.86 \\
Feed restriction (0\% Glyc) & 190 & 727 & 115 & 1.66 \\
Feed restriction (1\% Glyc) & 190 & 741 & 116 & 1.64 \\
Feed restriction (2\% Glyc) & 194 & 776 & 120 & 1.62 \\
CV (\%) & 2.2 & 2.8 & 2.3 & 2.9 \\
CONTRAST 1 & $*$ & ns & $*$ & $*$ \\
CONTRAST 2 & $*$ & ns & $*$ & $*$ \\
CONTRAST 3 & $*$ & $*$ & ns & $*$ \\
\hline Thermoneutral environment & & & & \\
\hline Treatment & Fl_24h & WC_24h & WG & FCR \\
\hline Control & 233 & 544 & 129 & 1.80 \\
Feed restriction (0\% Glyc) & 209 & 499 & 129 & 1.62 \\
Feed restriction (1\% Glyc) & 208 & 480 & 129 & 1.60 \\
Feed restriction (2\% Glyc) & 202 & 458 & 124 & 1.62 \\
CV (\%) & 2.6 & 4.1 & 3.2 & 2.4 \\
CONTRAST 1 & $*$ & $*$ & ns & $*$ \\
CONTRAST 2 & $*$ & $*$ & ns & $*$ \\
CONTRAST 3 & $*$ & $*$ & $*$ & $*$ \\
\hline
\end{tabular}

FI_24h: feed intake during a 24h period; WC_24h: Water consumptionduring a $24 \mathrm{~h}$ period; WG: Weight gain; BW: Body weight; FCR: feed conversion ratio; CV: coefficient of variation. ns: no significant; ${ }^{*}$ significant at $p<0.05$.

Contrast 1 - Control vs. 0\% glycerin

Contrast $2-$ Control vs. $1 \%$ glycerin

Contrast $3-$ Control vs. $2 \%$ glycerin 
Moraes POM, Ceron MS, Borille R,

Gianluppi RDF, Lovato GD,

Cardinal KM, Ribeiro AML
Effects of the Addition of Pure Glycerin

Supplementation in the Drinking Water on the

Performance of Broilers Submitted to Heat Stress and

Feed Restriction in agreement with the findings of Butzen et al. (2013) and Furlan et al. (2002). The WG of the birds receiving $0 \%$ and $1 \%$ GLYC was not different relative to the controls, but those fed $2 \%$ GLYC presented the lowest WG $(p<0.05)$, which may be explained by their lower WC and FI compared with those receiving $0 \%$ and $1 \%$ GLYC.

Feed restriction is a management practice recommended to prevent the mortality of broilers reared under high temperature and humidity (Ribeiro \& Laganá, 2002); however, no mortality was recorded in the present experiment (data not shown), possibly because the birds were reared at low density.

\section{CONCLUSION}

The inclusion of $2 \%$ pure glycerin in the drinking water may be used as a tool to improve the performance of broilers submitted to feed restriction and cyclic heat stress.

\section{REFERENCES}

Barbour E, Tayeb I, Shaib H, Ibrahim M. Physiological and carcass traits in heat-stressed broilers differing in heat acclimatization, chemical or feed restriction treatments. Agriculture and Biology Journal of North America 2010;1(2):65-74.

Butzen FM, Ribeiro AML, Vieira MM, Kessler AM, Dadalt JC, Della MP. Early feed restriction in broilers. I- Performance, body fraction weights, and meat quality. Journal Applied Poultry Research 2013;22 (2):251-259.

Cerrate S, Yan F, Wang Z, Coto C, Sacakli P, Waldroup P. Evaluation of glycerine from biodiesel production as a feed ingredient for broilers. International Journal of Poultry Science, 2013:5(11):1001-1007.

Coutts A, Reaburn P, Mummery K, Holmes M. The effect of glycerol hyperhydration on olympic distance triathlon performance in high ambient temperatures. International Journal of Sport Nutrition and Exercise Metabolism 2002;12(1):105-119.

De Basilio V, Vilarino M, Yahav, S, Picard M. Early age thermal conditioning and dual feeding program for male broilers challenged by heat stress. Poultry Science 2001;80(1):29-36.

Dozier WA, Kerr BJ, Corzo A, Kidd MT, Weber TE, Bregendahl K. Apparent metabolizable energy of glycerin for broiler chickens. Poultry Science 2008;87(2):317-322

Furlan R, Machado J, Giachetto P, Malheiros E, Furlan L, Macari M. Desempenho e composição da carcaça de frangos de corte submetidos a diferentes períodos de arraçoamento. Revista Brasileira de ZootElia 2002;31(6):2265-2273.

Gianfelici MF. Uso do glicerol como fonte de energia para frangos de corte [dissertation]. Porto Alegre (RS): Universidade Federal do Rio Grande do Sul, 2009.
Guerra RLH, Murakami AE, Garcia AFQ, Urgnani FJ, Moreira I, Picoli KP. Glicerina bruta mista na alimentação de frangos de corte (1 a 42 dias). Revista Brasileira de Saúde e Produção Animal 2011;12(4):1038-1050.

Kavouras SA, Armstrong L, Maresh C, Casa D, Herrera-Soto J, Scheett $\mathrm{T}$, et al. Rehydration with glycerol: endocrine, cardiovascular and thermoregulatory responses during exercise in the heat. Journal of Applied Physiology 2006;100(2):442-450.

Macari M, Furlan RL, Gonzales E. Fisiologia aviária aplicada a frangos de corte. $2^{\text {a }}$ ed. Jaboticabal: FUNEP; 2002.

Mushtaq M, Pasha T, Mushtaq T, Parvin R. Electrolytes, dietary electrolyte balance and salts in broilers: an updated review on growth performance, water intake and litter quality. World's Poultry Science Journal 2013;69(4):789-802.

Oba A, Lopes PCF, Boiago MM, Mary A, Silva S, Montassier H, et al. Características produtivas e imunológicas de frangos de corte submetidos a dietas suplementadas com cromo, criados sob diferentes condições de ambiente. Revista Brasileira de Zootecnia 2012;41(5):1186-1192.

O'brien C, Freund A, Young J, Sawka M. Glycerol hyperhydration: physiological responses during cold-air exposure. Journal of Applied Physiology 2005;99(2):515- 521.

Özkan S, Akbas Y, Altan O, Altan O, Ayhan V, Ozkan A. The effect of shortterm fasting on performance traits and rectal temperature of broilers during the summer season. British Poultry Science 2003;44(1):88- 95.

Patlar S, Yalçin H, Boyali E. The effect of glycerol supplements on aerobic and anaerobic performance of athletes and sedentary subjects. Journal of Human Kinects 2012;34(1):69-79.

Ribeiro AML, Laganá C. Estratégias nutricionais para otimizar a produção de frangos de corte em altas temperaturas [CD-Rom]. Anais do Encontro Internacional dos Negócios da Pecuária; 2002; Cuiabá, Mato Grosso. Brasil.

Ribeiro AML, Vogt LK, Canal CW, Laganá C, Streck AF. Suplementação de vitaminas e minerais orgânicos e sua ação sobre a imunocompetência de frangos de corte submetidos a estresse por calor. Revista Brasileira de Zootenia 2008;37(4):636-644.

Romano GG, Menten JFM, Freitas LW, Lima MB, Pereira R, Zavarize KC, et al. Effects of glycerol on the metabolism of broilers fed increasing glycerine levels. Brazilian Journal of Poultry Science 2014;16(1):97-106.

Rostagno HS, Albino LFT, Donzele JL. Tabelas brasileiras para aves e suínos: composição dos alimentos e exigências nutricionais. Viçosa: UFV; 2011.

Schott HC, Patterson KS, Eberhart SW. Glycerol hyperhydration in resting horses. Veterinary Journal 2001;161(2):194-204.

Smith M, Teeter R. Effects of potassium chloride supplementatoin growth of heat-distreseed broilers. Journal of Applied Poultry Research $1992 ; 1(3): 21-324$

Yalçin S, Settar P, Ozkan S, Cahaner A. Comparative evaluation of three commercial broiler stocks in hot versus temperate climates. Poultry Science 1997;76(7)921-929.

Yahav S, Straschnow A, Plavnik I, Hurwitz S. Effects of diurnal cycling versus constant temperatures on chicken growth and food Intake. British Poultry Science 1996;37(1):43-54. 
